\title{
COMPARATIVE EFFICACY OF DIFFERENT WEED MANAGEMENT STRATEGIES IN WHEAT
}

\author{
Muhammad Ehsan Safdar ${ }^{*}$, Muhammad Asif ${ }^{1}$, Amjed Ali ${ }^{1}$, Ahsan Aziz ${ }^{1}$, Muhammad Yasin ${ }^{1}$, \\ Mudassir Aziz ${ }^{1}$, Muhammad Afzal ${ }^{1}$, and Asghar Ali ${ }^{2}$
}

\begin{abstract}
Weed management programs should focus on environmental safety along with benefits to the farmer. We evaluated the effects of various weed control methods: 'daab' practice (stale seed bed technique), manual hoeing, and the chemical method (mixture of Buctril Super 60EC [bromoxynil + MCPA] $0.45 \mathrm{~kg}$ ai ha-1 and Puma Super 75EW [fenoxaprop-P-ethyl] $0.75 \mathrm{~kg}$ ai ha ${ }^{-1}$ ) in combination with different planting geometries: $22.5 \mathrm{~cm}$ apart single row, $22.5 \mathrm{~cm}$ apart crisscross double row, $30 \mathrm{~cm}$ apart single row and broadcast sowings on weed control and grain yield of spring wheat (Triticum aestivum L.) var. Sehar 2006 at the University College of Agriculture, University of Sargodha, Pakistan, during the winters of 2009 and 2010. The chemical method, manual hoeing and 'daab' practice gave $71.44 \%, 30.69 \%$ and $28.60 \%$ weed controls resulting in $11.79 \%, 11.09 \%$ and $4.95 \%$ increases in grain yield above that of the weedy control, respectively. The $22.5 \mathrm{~cm}$ apart single row sowing in combination with chemical weed control proved to be the best regarding weed control $(87.23 \%)$, grain yield $\left(4073 \mathrm{~kg} \mathrm{ha}^{-1}\right)$ and number of fertile tillers $\mathrm{m}^{-2}(509.5)$, whereas wheat plant height $(108.2 \mathrm{~cm})$, number of grains spike ${ }^{-1}(45.90)$ and 1000 grain weight $(45.23 \mathrm{~g})$ were higher in $30 \mathrm{~cm}$ apart single row sowing in interaction with manual hoeing. Grain yield showed a significant negative $(b=-152.8)$ and positive $(b=3.21)$ correlation with weed biomass and fertile tillers $\mathrm{m}^{-2}$, respectively. Chemical weed control, 'daab' practice and manual hoeing gave cost:benefit ratios of $2.50,1.95$ and 1.14 , respectively. Although the chemical method seems the most profitable, the 'daab' practice was found to be the most advantageous if environmental concerns were taken into consideration.
\end{abstract}

Key words: Weed control, sowing pattern, 'daab’ practice, crisscross sowing, yield components.

$\mathrm{W}$ heat (Triticum aestivum L.) is one of the most important cereals and is grown extensively throughout the world. It is the main staple food and largest grain crop of Pakistan. In many countries like Pakistan, despite the concrete efforts of government, agronomists and farmers, the average national per hectare yield of wheat still remains far below potential yield. Weed infestation is among the important factors for low yields (Cheema and Farooq, 2007). In Pakistan, reduction in wheat yields due to weeds is $20-30 \%$ (Abbas, 2006). Weeds reduce crop yield not only by competing for necessary growth factors such as water, nutrients, light and space, but also by releasing allelochemicals in the rhizosphere through their roots or other plant parts (Reddy, 2000).

${ }^{1}$ University College of Agriculture, University of Sargodha, Sargodha, Punjab, Pakistan.

*Corresponding author(ehsan_safdar2002@yahoo.com).

${ }^{2}$ University of Agriculture, Department of Agronomy, Faisalabad, Punjab, Pakistan.

Received: 5 October 2010.

Accepted: 25 December 2010.
The various methods that are most widely used in the country for controlling weeds are physical, mechanical, cultural and chemical. Among the physical and mechanical methods are hoeing and intercropping; cultural methods include the stale seedbed or 'daab' technique and crop rotation; and chemical methods involve the use of herbicides (Ahmad and Shaikh, 2003; Klein et al., 2006). 'Daab' or delayed sowing, also known as the false (stale) seed bed technique involves delaying final seedbed preparation in order to stimulate as much as possible the emergence of weeds prior to sowing (Labrada, 2003). Each of these methods has its own advantages and disadvantages. Weed management through physical and mechanical means involves labor, animal and implement costs, making them more laborious, tiresome and expensive (Iqbal, 1994). On the other hand, reliance solely on chemical weed control involves excessive use of herbicides, resulting in pollution of the environment and inter- and intra-specific shifts (Hassan and Marwat, 2001) due to the development of more competitive herbicide-resistant biotypes within a plant population or 
community (Shrestha et al., 2010). In addition, herbicide use reduces $\mathrm{N}$-uptake in wheat (Azad, 1997), leading to low growth and yields. This is especially true in the case of non-selective herbicides, as reported by Malhi et al. (2007), who observed a significant reduction in plant $\mathrm{N}$ uptake in wheat by applying a mixture of non-selective (glyphosate) and selective (2,4-D) herbicides.

Weed management programs, should therefore neither rely totally on chemical or mechanical means due to their respective potential risks and costs. Moreover, programs should integrate curative methods with preventive methods. Preventive methods are employed before weed appearance or crop sowing, whereas curative methods control weeds in already established crop (Labrada, 2003). One such strategy is the combination of cultural or ecological weed control with chemical weed control. Cultural weed control involves manipulation of the crop/weed environment so that conditions become more favorable for crop than weeds (Klein et al., 2006).

Among cultural weed control methods, 'daab' can reduce weed emergence $>80 \%$, resulting in a $69 \%$ increase in wheat yield compared to standard seedbed preparation (Van der Weide et al., 2002; Lyon et al., 2006). Another cultural weed control method is close planting of wheat through reducing row spacing below what is recommended (Lyon et al., 2006). Narrow row widths reduce the biomass of later-emerging weeds by decreasing the light available for weeds located below the crop canopy (OMAFRA, 2002).

Adopting both methods ('daab' and close planting geometry) can be an effective and economic weed control strategy and the basis for a cost-effective, eco-friendly and sustainable weed management program. Therefore, the objective of this study was to evaluate the effectiveness of different planting geometries in interaction with weed control methods for reducing weed infestation and maximizing grain yield of wheat on an economic basis.

\section{MATERIALS AND METHODS}

Two-year field studies were carried at the Research Area, University College of Agriculture, University of Sargodha, Sargodha, Pakistan, during 2009 and 2010, to evaluate the effect of different weed management strategies and planting geometries on weed control and ultimate wheat grain yield. The experiment was comprised of four weed management practices: 'daab' practice, standard seed bed preparation + no weed control, standard seed bed preparation + one hoeing, and standard seed bed preparation + chemical weed control; and four planting geometries: $22.5 \mathrm{~cm}$ apart single row planting, 22.5 apart crisscross double row planting, $30 \mathrm{~cm}$ apart single row and broadcast sowing. The experiment was laid down in a randomized complete block design with a split plot arrangement with the weed management practices in the main plot and planting geometries in sub-plots having a net sub-plot size of $2.5 \times 3.0 \mathrm{~m}$, with three replicates.

Spring wheat var. Sehar 2006 was used as a test crop. Soil of the experimental field was sandy loam in nature. During each year, hoeing was carried out manually using 'kasula' and 'khurpa', the conventional inter-tillage hand tools for controlling inter- and intra row weeds, respectively, $40 \mathrm{~d}$ after sowing, whereas chemical weed control was accomplished with a mixture of Buctril Super 60EC (bromoxynil [3,5-dibromo-4-hydroxybenzonitrile] + MCPA [4-chloro-o-tolyloxyacetic acid) $0.45 \mathrm{~kg}$ ai ha-1 and Puma Super 75EW (fenoxaprop-p-ethyl $(R)$-2-[4(6-chloro-1,3-benzoxazol-2-yloxy) phenoxy] propionic acid) $0.75 \mathrm{~kg}$ ai ha ${ }^{-1}$ for broadleaf weeds and grasses, respectively, were sprayed after $21 \mathrm{~d}$ of sowing. In the case of 'daab' or delayed sowing treatment, soaking irrigation was applied $7 \mathrm{~d}$ earlier than with the other treatments and soil was subjected to planking to conserve moisture when it attained workable conditions. Furthermore, sowing was delayed for another week. According to the sowing plan, seed was sown manually with the help of a single row hand drill on 10 and 15 December in 2009 and 2010, respectively, keeping the seed rate of $125 \mathrm{~kg} \mathrm{ha}^{-1}$ in each year. $125 \mathrm{~kg} \mathrm{~N} \mathrm{ha}^{-1}$ and $80 \mathrm{~kg} \mathrm{P} \mathrm{ha}^{-1}$ were applied in the form of urea and di-ammonium phosphate (DAP), respectively.

Data on weed dry weight and plant height were taken $15 \mathrm{~d}$ before crop harvest. Weed dry weight was recorded by uprooting all the weeds in a $1 \mathrm{~m}^{2}$ quadrant (sampling units, each $1 \mathrm{~m}$ in length and width) placed at random in each plot. Weed samples were then dried in an oven at 70 ${ }^{\circ} \mathrm{C}$ for $48 \mathrm{~h}$. Yield and yield components were recorded at harvest using the standard procedure. Data from both years were averaged and subjected to statistical analysis using Fisher's analysis of variance technique and the treatment means were compared by the Least Significance Difference (LSD) test at 5\% probability. Moreover, the effects of other parameters on grain yield were assessed through regression analyses (Steel et al., 1997). Economic analysis of all weed management strategies was carried out on the basis of their net profits and cost:benefit $(\mathrm{C}: \mathrm{B})$ ratios.

\section{RESULTS AND DISCUSSION}

Data pertaining to the effect of different weed control practices and planting geometries on weed biomass (Table 1) show that there was a significant effect of weed management practices, as well as planting geometries on weed dry weight. All weed control practices produced significantly lower weed biomass than the weedy control 


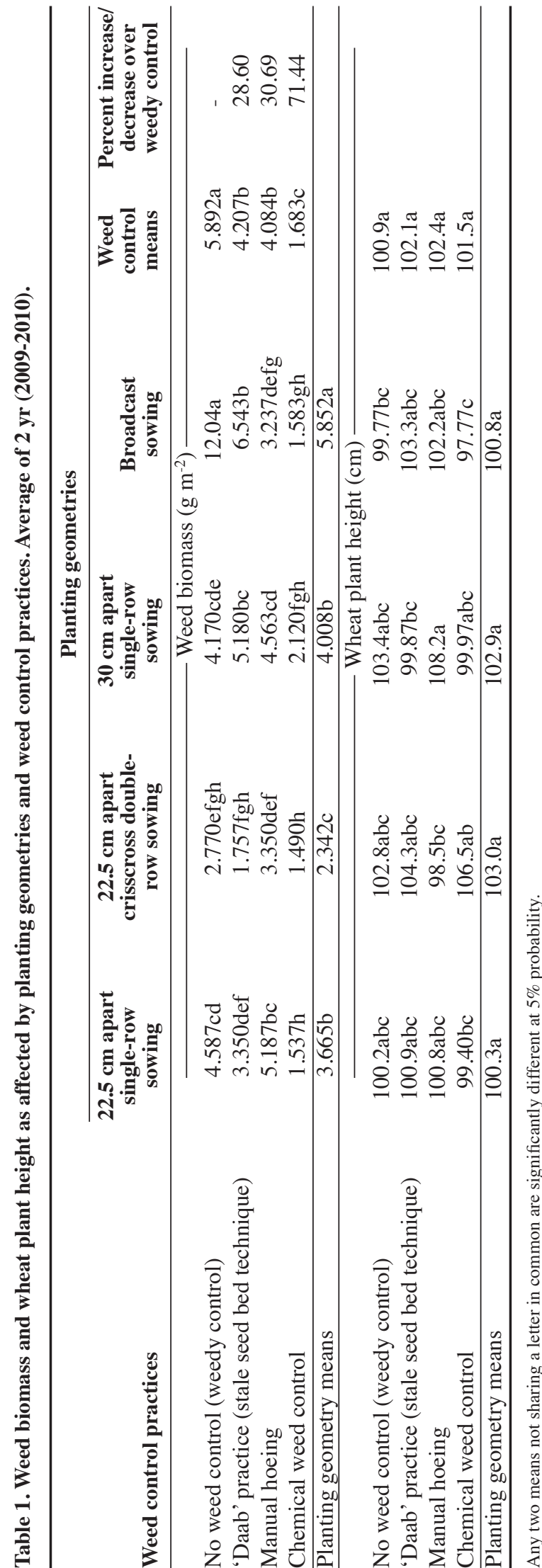

(5.892 $\mathrm{g} \mathrm{m}^{-2}$ ) and minimum dry weight was recorded in the chemical weed control $\left(1.683 \mathrm{~g} \mathrm{~m}^{-2}\right)$. The 'daab' practice, manual hoeing and chemical weed control gave $28.60 \%, 30.69 \%$ and $71.44 \%$ weed control, respectively above that of the weedy control (Table 1). Comparison of different planting geometries shows that minimum weed biomass $\left(2.342 \mathrm{~g} \mathrm{~m}^{-2}\right)$ was produced in the $22.5 \mathrm{~cm}$ apart crisscross double-row planting, which was significantly lower than other planting geometries, whereas weed dry weight was the highest in broadcast sowing $(5.852 \mathrm{~g}$ $\mathrm{m}^{-2}$ ). The interaction between weed control practices and fertilizer levels was significant.

The minimum dry weight $\left(1.490 \mathrm{~g} \mathrm{~m}^{-2}\right)$ was recorded in $22.5 \mathrm{~cm}$ apart crisscross double-row sowing subjected to chemical weed control, which was statistically similar to the 'daab' practice $\left(1.757 \mathrm{~g} \mathrm{~m}^{-2}\right)$ and weedy control $\left(2.77 \mathrm{~g} \mathrm{~m}^{-2}\right)$, as well as $22.5 \mathrm{~cm}$ apart single-row sowing $\left(1.537 \mathrm{~g} \mathrm{~m}^{-2}\right)$ in the chemical weed control, $30 \mathrm{~cm}$ apart single-row sowing $\left(2.12 \mathrm{~g} \mathrm{~m}^{-2}\right)$ and broadcast sowing $\left(1.583 \mathrm{~g} \mathrm{~m}^{-2}\right)$. The maximum weed biomass $\left(12.04 \mathrm{~g} \mathrm{~m}^{-2}\right)$ was recorded in the case of no weed control with broadcast sowing, compared to all the other combinations.

Weed dry weight showed a highly significant negative correlation with grain yield at $5 \%$ probability level with regression coefficient of -152.8 (Figure 1). The lowest weed biomass in chemical weed control was due to the activity of herbicides that reduced weed density by killing both broadleaf and narrow leaf weeds and suppressing the growth of those that remained in field. 'Daab' practice and manual hoeing also resulted in lower weed biomass due to uprooting of weeds that germinated before crop sowing and early growth stages of the crop, respectively. 'Daab' produced suitable conditions in the field for germination of weeds that emerged and were uprooted during final seedbed preparation, thus minimizing the weed seed bank in the soil. Maximum weed biomass was found in weedy control where no weed management strategy was employed throughout the crop growth period. These findings are in line with those reported by Hooda and Agrawal (1991; 1997) and Das and Yaduraju (1999), who also observed maximum weed dry weight in the weedy control.

The minimum weed biomass in $22.5 \mathrm{~cm}$ apart crisscross double-row sowing was due to the uniform density of wheat plants in this treatment, which allowed only a few weed plants to emerge and grow. Weed biomass gradually increased with the increase in row spacing from $22.5 \mathrm{~cm}$ apart single rows to $30 \mathrm{~cm}$ apart single rows. Whereas, in the case of broadcast sowing, the weed dry weight was higher due to the non-uniform crop stand, which led to over-crowding and thin-stemmed and weak wheat seedlings that were unable to efficiently compete with weeds. The combination of broadcast sowing with 


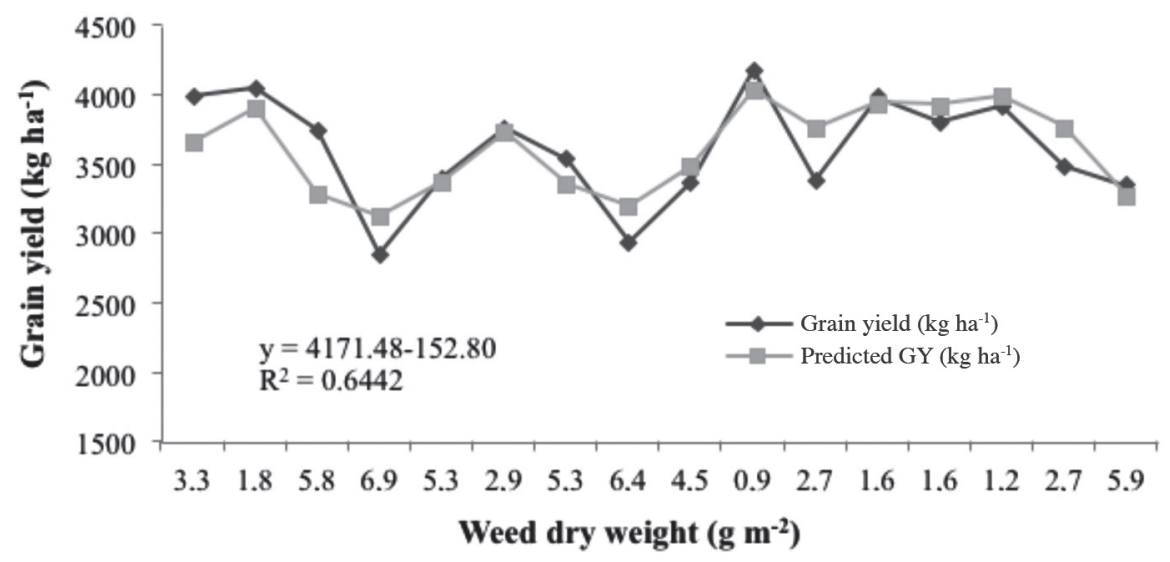

Figure 1. Regression analysis of grain yield (GY, $\left.\mathrm{kg} \mathrm{ha}^{-1}\right)$ as affected by weed dry weight $\mathrm{m}^{-2}$.

no weed control yielded the highest weed biomass. On the other hand, $22.5 \mathrm{~cm}$ apart crisscross double-row sowing in interaction with chemical weed control produced the lowest weed biomass due to the combined effect of herbicides and rapid shading of ground with closely planted crop rows. These results concur with those found by Sharma et al. (1985), Pandey and Dwivedi (2007), Abbas et al. (2009), and Chachar et al. (2009), who also found that close planting ( 22.5 to $15 \mathrm{~cm}$ row to row distance) combined with chemical weed control gave minimum dry weed weight and maximum weed control.

Plant height reflects the vegetative growth pattern of the plant. The effect on plant height of different weed control practices and planting geometries was nonsignificant, as shown by their means (Table 1). However, interaction of the two factors significantly affected plant height. The highest plants $(108.2 \mathrm{~cm})$ were observed in the $30 \mathrm{~cm}$ apart single-row sowing treatment, which was statistically non-significant from those recorded in the other treatment combinations, except in $30 \mathrm{~cm}$ apart single row sowing with the 'daab' practice $(99.87 \mathrm{~cm})$, broadcast sowing with no weed control $(99.77 \mathrm{~cm}), 22.5 \mathrm{~cm}$ apart single row planting with chemical weed control (99.40 $\mathrm{cm})$, and crisscross double row planting with hoeing $(98.47 \mathrm{~cm})$. However, the lowest plant height $(97.77 \mathrm{~cm})$ was attained in broadcast sowing with chemical weed control.

Plant height had a non-significant positive relationship with grain yield (Figure 2). Plant height is a varietal character more affected by the genotype than by the environment. Therefore weed control practices and planting geometries alone did not impose a significant effect. However, interaction of these factors, to some extent, significantly altered plant height. The highest plants in the $30 \mathrm{~cm}$ apart single-row sowing treatment in combination with manual hoeing might have been due to wider plant spacing and suitable soil conditions produced by hoeing, which favored continuous vegetative growth leading to taller plants. Conversely, the lowest plant height was recorded in broadcast sowing with chemical weed control. This may be attributed to the nonuniform sowing depth resulting in poor root and shoot

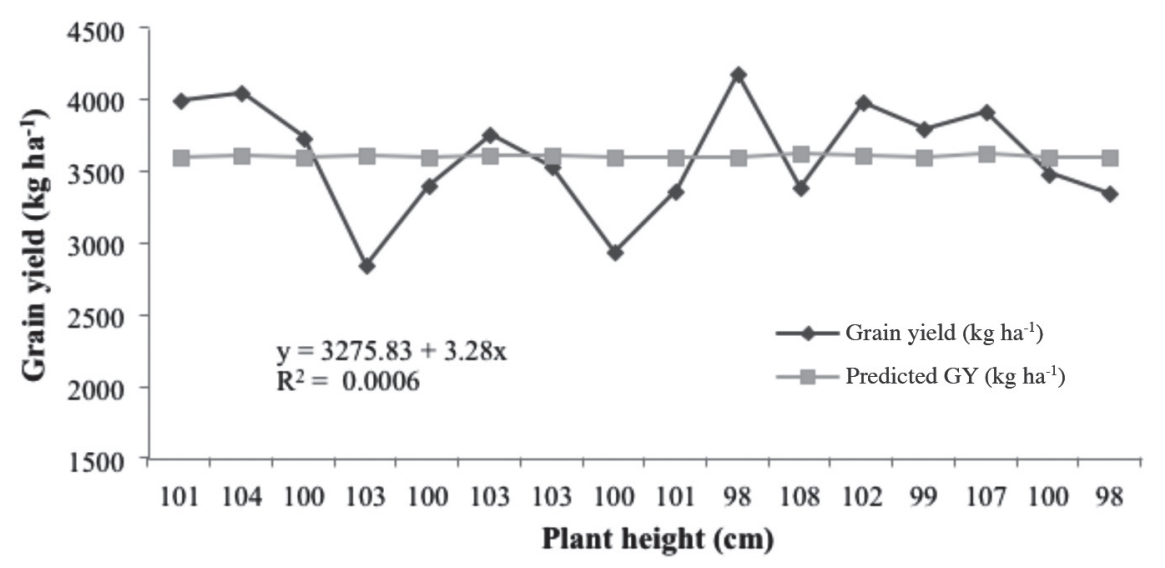

Figure 2. Regression analysis of grain yield (GY, $\left.\mathrm{kg} \mathrm{ha}^{-1}\right)$ as affected by plant height $(\mathrm{cm})$. 
growth of wheat seedlings, further aggravated by the growth inhibition on these seedlings by the phytotoxic herbicidal compounds. The results were not in full conformity with those of Chachar et al. (2009), who found maximum plant height of wheat in the treatment where close planting (15 $\mathrm{cm}$ row to row distance) with chemical weed control.

Grain yield is the result of productive tillers per unit area, number of grains per spike, and grain weight, all considered yield components. Of these yield components, the number of grains per spike and 1000-grains weight are determined mainly by genetics and therefore generally are not affected as much by environmental conditions. On the other hand, the number of tillers per unit area is the parameter that is most affected by the environment, and hence changes with prevailing growing conditions. The number of fertile tillers $\mathrm{m}^{-2}$ was not significantly affected by weed control practices (Table 2). However, planting geometries and their interaction with weed control practices significantly influenced this yield component. Among planting geometries, the highest number of fertile tillers $\mathrm{m}^{-2}$ (447.9) was in the 22.5 $\mathrm{cm}$ apart single row-sowing treatment, which was statistically similar to those recorded in the other planting geometries, except broadcast sowing, which produced the lowest number of fertile tillers $\mathrm{m}^{-2}$ (365.0). Comparing interactions, $22.5 \mathrm{~cm}$ apart singlerow sowing in combination with chemical weed control resulted in the highest number of fertile tillers $\mathrm{m}^{-2}$ (509.5), whereas broadcast sowing in interaction with no weed control produced the lowest number of tillers $\mathrm{m}^{-2}$ (327.4). The other interactions remained statistically similar to either the highest or lowest values of this parameter. Similar findings have been reported by the Chachar et al. (2009), who found the highest value of this parameter in $22.5 \mathrm{~cm}$ apart singlerow sowing subjected to chemical weed control.

Regression analysis, as depicted in Figure 3, showed a significant positive effect on grain yield of wheat with a regression coefficient (b) of 3.21. A higher number of fertile tillers in $\mathrm{m}^{-2}$ in $22.5 \mathrm{~cm}$ apart and $30 \mathrm{~cm}$ apart single-row sowing treatments may be partially due to less weed competition with crop plants for water, nutrients and other growth factors, and partially due to the optimum space for wheat plants to flourish and produce productive tillers up to their potential. However, by reducing plant spacing further, as in case of $22.5 \mathrm{~cm}$ apart crisscross double-row sowing and broadcast sowing, the number of fertile tillers decreased. The highest number of productive tillers in $22.5 \mathrm{~cm}$ apart single-row sowing in interaction with chemical weed control may be attributed to further reduction of weed competition.

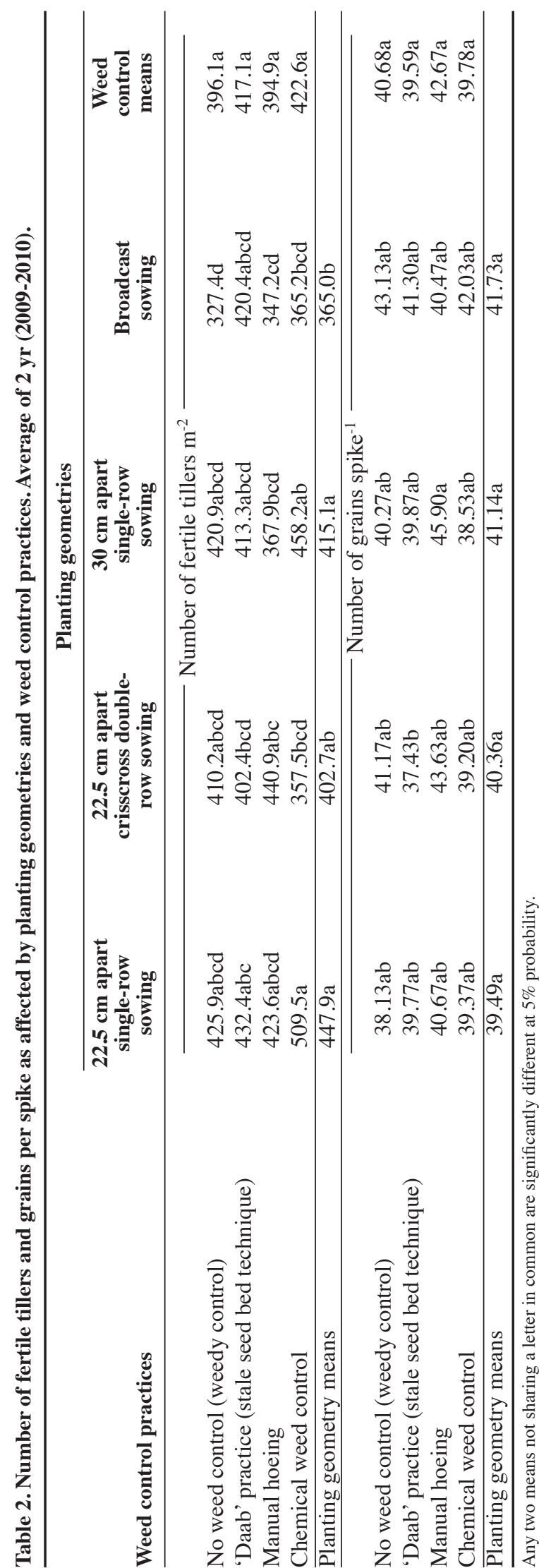




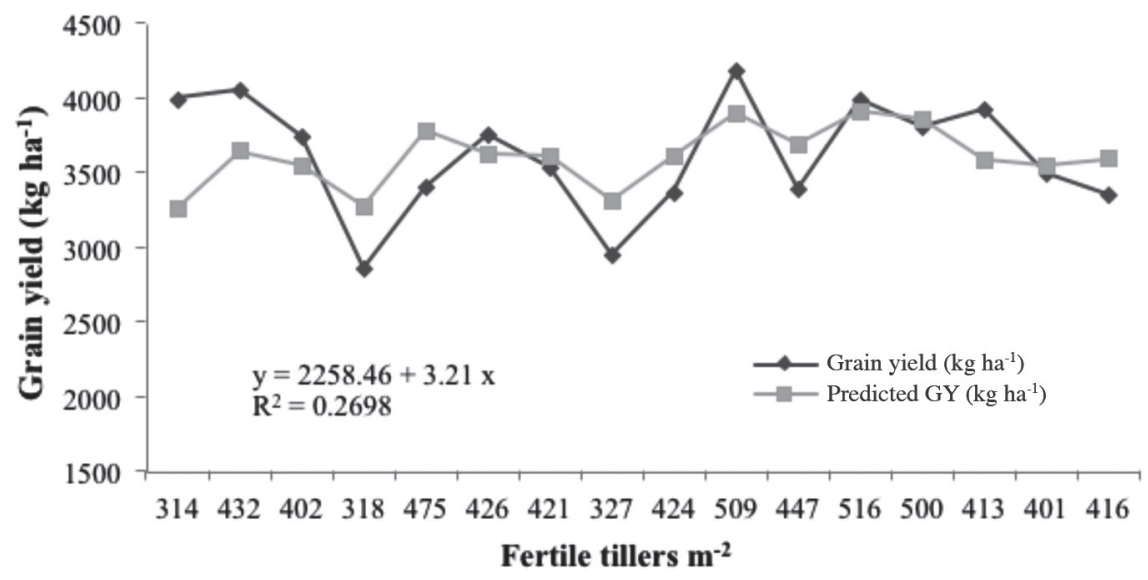

Figure 3. Regression analysis of grain yield (GY, $\left.\mathrm{kg} \mathrm{ha}^{-1}\right)$ as affected by fertile tillers $\mathrm{m}^{-2}$.

The number of grains per spike of wheat was not significantly affected by the different weed control practices or planting geometries (Table 2). However, the planting geometry and weed control practice interaction did show significant effects. The $30 \mathrm{~cm}$ apart single-row sowing treatment produced the highest number of grains spike $^{-1}$ (45.90) in interaction with manual hoeing and was non-significantly different from all other interactions except that recorded in $22.5 \mathrm{~cm}$ apart crisscross doublerow sowing in combination with the 'daab' practice (37.43), which was non-significantly and positively correlated with grain yield (Figure 4). The high number of grains spike ${ }^{-1}$ in $30 \mathrm{~cm}$ apart single-row sowing with chemical weed control was probably due to increased plant height, which led to longer spikes and a larger number of grains. These results are in line with those of Chachar et al. (2009), who reported the highest value of spikelets plant ${ }^{-1}$ in the chemical weed control.

Weed control practices were unable to produce significant differences in 1000-grain weight (Table 3). However, among various planting geometries, 30 $\mathrm{cm}$ apart single-row geometry achieved the highest 1000-grain weight (42.47 g), which was statistically similar to those recorded with other planting geometries, except broadcast sowing, which produced $39.89 \mathrm{~g}$ 1000-grain weight. Comparison of interactions revealed that the highest 1000 -grain weight $(45.23 \mathrm{~g})$ was attained by $30 \mathrm{~cm}$ apart single-row planting with manual hoeing, whereas the lowest value (39.12) of this parameter was noted in $22.5 \mathrm{~cm}$ apart crisscross double-row sowing with chemical weed control. The other interactions remain statistically at par with either the highest value or the lowest value of this parameter. Regression analysis (Figure 5) revealed 1000-grain weight had a nonsignificant positive correlation with grain yield. Chachar et al. (2009) also reported higher 1000-grain weight in widely spaced rows with chemical weed control in contrast to lower 1000-grain weight in close-row spacing

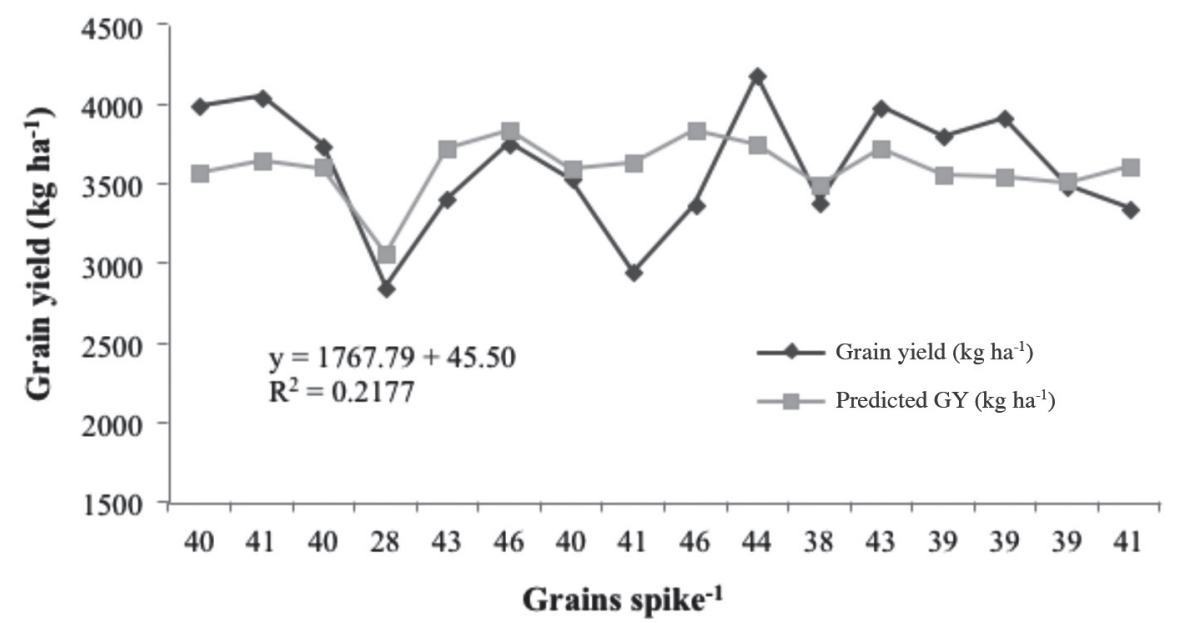

Figure 4. Regression analysis of grain yield (GY, $\left.\mathrm{kg} \mathrm{ha}^{-1}\right)$ as affected by grains spike-1. 

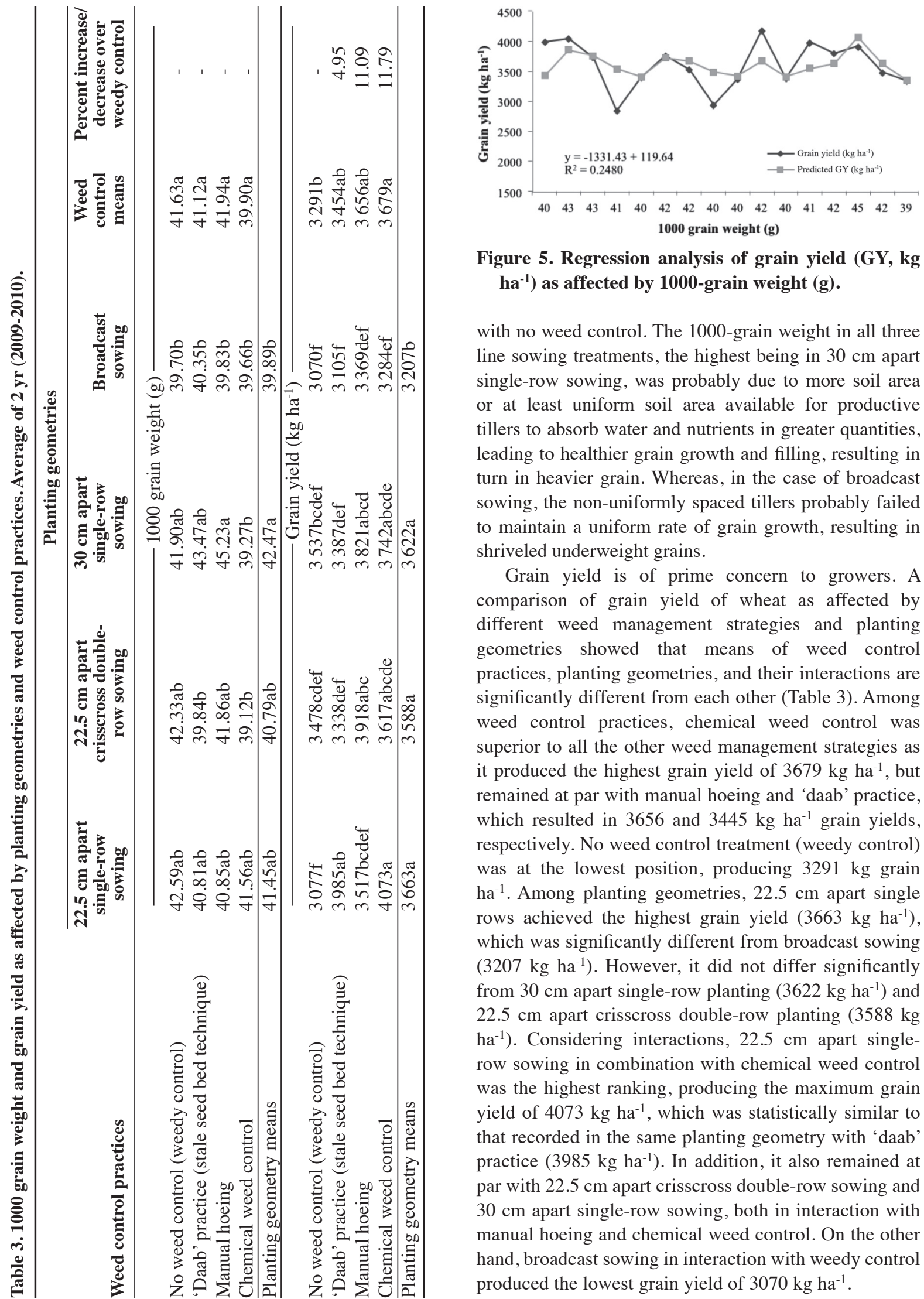

Figure 5. Regression analysis of grain yield (GY, kg $\left.\mathrm{ha}^{-1}\right)$ as affected by 1000-grain weight $(\mathrm{g})$.

with no weed control. The 1000-grain weight in all three line sowing treatments, the highest being in $30 \mathrm{~cm}$ apart single-row sowing, was probably due to more soil area or at least uniform soil area available for productive tillers to absorb water and nutrients in greater quantities, leading to healthier grain growth and filling, resulting in turn in heavier grain. Whereas, in the case of broadcast sowing, the non-uniformly spaced tillers probably failed to maintain a uniform rate of grain growth, resulting in shriveled underweight grains.

Grain yield is of prime concern to growers. A comparison of grain yield of wheat as affected by different weed management strategies and planting geometries showed that means of weed control practices, planting geometries, and their interactions are significantly different from each other (Table 3 ). Among weed control practices, chemical weed control was superior to all the other weed management strategies as it produced the highest grain yield of $3679 \mathrm{~kg} \mathrm{ha}^{-1}$, but remained at par with manual hoeing and 'daab' practice, which resulted in 3656 and $3445 \mathrm{~kg} \mathrm{ha}^{-1}$ grain yields, respectively. No weed control treatment (weedy control) was at the lowest position, producing $3291 \mathrm{~kg}$ grain $\mathrm{ha}^{-1}$. Among planting geometries, $22.5 \mathrm{~cm}$ apart single rows achieved the highest grain yield $\left(3663 \mathrm{~kg} \mathrm{ha}^{-1}\right)$, which was significantly different from broadcast sowing (3207 kg ha-1). However, it did not differ significantly from $30 \mathrm{~cm}$ apart single-row planting $\left(3622 \mathrm{~kg} \mathrm{ha}^{-1}\right)$ and $22.5 \mathrm{~cm}$ apart crisscross double-row planting $(3588 \mathrm{~kg}$ $\left.\mathrm{ha}^{-1}\right)$. Considering interactions, $22.5 \mathrm{~cm}$ apart singlerow sowing in combination with chemical weed control was the highest ranking, producing the maximum grain yield of $4073 \mathrm{~kg} \mathrm{ha}^{-1}$, which was statistically similar to that recorded in the same planting geometry with 'daab' practice $\left(3985 \mathrm{~kg} \mathrm{ha}^{-1}\right)$. In addition, it also remained at par with $22.5 \mathrm{~cm}$ apart crisscross double-row sowing and $30 \mathrm{~cm}$ apart single-row sowing, both in interaction with manual hoeing and chemical weed control. On the other hand, broadcast sowing in interaction with weedy control produced the lowest grain yield of $3070 \mathrm{~kg} \mathrm{ha}^{-1}$. 
The percentage yield increase above that of the weedy control was highest with the chemical weed control (11.79\%), followed by manual hoeing (11.09\%), whereas, there was only a $4.95 \%$ increase in grain yield. The composite of differences in yield components was reflected in the form of grain yield. Significantly higher grain yield in $22.5 \mathrm{~cm}$ apart single-row sowing subjected to chemical weed control was probably the result of lower weed dry weight and the higher number of fertile tillers produced in this treatment combination. The predominant effect of these two parameters on final grain yield was also confirmed by regression analyses of grain yield. These observations are in line with those reported by Sharma et al. (1985) and Abbas et al. (2009) who found that chemical weed control in combination with $22.5 \mathrm{~cm}$ single-row sowing, cross-row sowing, or closer spaced rows of $15 \mathrm{~cm}$ reduced weed competition and resulted in increased grain yields of wheat. Ashrafi (2009) also found a significantly higher grain yield in 20 $\mathrm{cm}$ row spacing subjected to broad-spectrum herbicide spray. In contrast, the weedy control had the lowest grain yield. This may due to severe weed competition that significantly reduced grain yield to a level lower than those in other weed management practices. Significantly lower grain yield in the weedy control compared to chemical and non-chemical weed control was also reported by Das and Yaduraju (1999) and Abbas et al. (2009).

Economic analysis of different weed control methods (Table 4) revealed that the chemical weed control resulted in the highest net return (Rs $104667 \mathrm{ha}^{-1}$ ), whereas manual hoeing (Rs $102243 \mathrm{ha}^{-1}$ ) remained at second and 'daab' practice (Rs $99697 \mathrm{ha}^{-1}$ ) at third position. No weed control gave the lowest net return (Rs $96533 \mathrm{ha}^{-1}$ ). Regarding the cost:benefit ratio $(\mathrm{C}: \mathrm{B})$, the chemical weed control was again superior to the others as it gave Rs 2.5 by costing only one rupee. However, the 'daab' practice remained at second $(\mathrm{BCR}=1.95)$ and manual hoeing at third position $(B C R=1.14)$. Although manual hoeing gave a higher net income than the 'daab' practice, it resulted in a lower $\mathrm{BCR}$ than that of the 'daab' practice.

\section{CONCLUSIONS}

Of the four weed management practices studied, the chemical weed control is best regarding grain yield, manual hoeing could be considered in second position and 'daab' in third. Moreover, chemical weed control gave the best results when sowing was carried out in 22.5 $\mathrm{cm}$ apart single rows. Considering the economics of these treatments, again chemical weed control is the best, but 'daab' practice is more profitable than manual hoeing as it gave more benefit per unit of its cost (cost:benefit ratio) 
compared to that given by manual hoeing. Furthermore, 'daab' performed best in $22.5 \mathrm{~cm}$ apart single-row sowing. The comparative advantages of 'daab' practice over chemical weed control are that it is preventive in nature, environmentally friendly, sustainable and free of hazards to human beings and animals. Therefore it may be concluded that the 'daab' practice, along with $22.5 \mathrm{~cm}$ apart single-row sowing is the best weed management strategy.

\section{RESUMEN}

Eficacia comparativa de distintas estrategias en el manejo de malezas en trigo. El programa de manejo de malezas también debe centrarse en la seguridad del medio ambiente junto con el beneficio de agricultores. Se evaluó el efecto de diferentes métodos de control de malezas, es decir, la práctica 'daab' (técnica de la falsa cama de la semilla), azada manual, y el método químico (Buctril Super 60EC [bromoxinil + MCPA] 0,45 kg ia $\mathrm{ha}^{-1} \mathrm{y}$ Super Puma 75EW [fenoxaprop-P-etil] 0,75 kg ia $\mathrm{ha}^{-1}$ ) en combinación con la plantación en diferentes geometrías: $22,5 \mathrm{~cm}$ de distancia en una hilera, $22,5 \mathrm{~cm}$ dos hileras entrecruzadas, $30 \mathrm{~cm}$ de separación en una hilera, y siembras al voleo sobre el control de malezas y el rendimiento de grano de trigo de primavera (Triticum aestivum L.) var. Sehar 2006 de la University College of Agriculture, University of Sargodha, Pakistán, durante los inviernos de 2009 y 2010. Método químico, azada manual y la práctica 'daab' dieron $71,44 \%, 30,69 \%$ y $28,60 \%$ de control de malezas que resultaron en aumentos de $11,79 \%$, $11,09 \%$ y $4,95 \%$ en rendimiento de grano sobre el control con maleza, respectivamente. La distancia de siembra de $22,5 \mathrm{~cm}$ en una hilera, en combinación con el control de malezas químico fue el mejor control de malezas $(87,23 \%)$ en relación con el rendimiento de grano $\left(4073 \mathrm{~kg} \mathrm{ha}^{-1}\right)$ y el número de macollos fértiles $\mathrm{m}^{-2}(509,5)$, mientras que la altura de planta de trigo $(108,2 \mathrm{~cm})$, número de granos por espiga $(45,90)$ y peso de 1000 granos $(45,23$ g) se mantuvieron más altos en siembra a $30 \mathrm{~cm}$ de distancia en una fila en interacción con escarda manual. El rendimiento de grano mostró una correlación significativa negativa $(b=-152,8)$ y positiva $(b=3,21)$ con la biomasa de las malezas y tallos fértiles de $2 \mathrm{~m}$, respectivamente. El control químico de malezas, la práctica 'daab' y escarda manual dieron relaciones costo:beneficio de 2,50; 1,95 y 1,14 , respectivamente. Aunque el método químico parece más rentable, pero al mismo tiempo teniendo en cuenta las preocupaciones ambientales, la práctica 'daab' fue más ventajosa.

Palabras clave: control de malezas, geometría de plantación, práctica ‘daab', componentes del rendimiento.

\section{LITERATURE CITED}

Abbas, M.A. 2006. General agriculture. Field crop production and management $4^{\text {th }}$ ed. 174 p. Publishers Emporium, Ahata Shahdarian, Urdu Bazar, Lahore, Pakistan.

Abbas, S.H., M. Saleem, M. Maqsood, M.Y. Mujahid, Mahmood-ul-Hassan, and R. Saleem. 2009. Weed density and grain yield of wheat as affected by spatial arrangements and weeding techniques under rainfed conditions of Pothowar. Pakistan Journal of Agricultural Science 46:242-247.

Ahmad, R., and A.S. Shaikh. 2003. Common weeds of wheat and their control. Pakistan Journal of Water Resources 7:73-76.

Ashrafi, Z.Y. 2009. Study of integrate methods chemical and cultural control of weeds to wheat (Triticum aestivum L.) Journal of Agricultural Sciences 1:113119.

Azad, B.S. 1997. Influence of nitrogen and isoproturon on nutrient uptake by weeds and wheat (Triticum aestivum). Indian Journal of Agronomy 42:471473.

Chachar, Q.I., M.A. Chachar, and S.D. Chachar. 2009. Studies on integrated weed management in wheat (Triticum aestivum L.) Journal of Agricultural Technology 5:405-412.

Cheema, Z.A., and M. Farooq. 2007. Agriculture in Pakistan. Agriculture in Pakistan: Problems of small farmers and their solutions. 23 p. Allied Book Center, Urdu Bazar, Lahore, Pakistan.

Das, T.K., and N.T. Yaduraju. 1999. Effect of weed competition on growth, nutrient uptake and yield of wheat as affected by irrigation and fertilizers. Journal of Agricultural Science 133:45-51.

Hassan, G., and K.B. Marwat. 2001. Integrated weed management in agricultural crops. In Proceedings of National Workshop on Technologies for Sustainable Agriculture, Faisalabad. 24-26 September 2001. Nuclear Institute for Agriculture and Biology (NIAB), Faisalabad, Pakistan.

Hooda, I.S., and S.K. Agrawal. 1991. Studies on population and dry matter production of weeds as affected by variation in irrigation, weedicides and fertility levels. Haryana Journal of Agronomy 7:6369.

Hooda, I.S., and S.K. Agrawal. 1997. Response of weeds to levels of irrigation, weed control and fertility in wheat. In Proceedings of International Crop Protection Conference-Weeds, Brighton. 17-20 November 1997. British Crop Protection Council, Brighton, UK. 
Iqbal, S. 1994. Screening of different herbicides for controlling weeds in wheat crop. M.Sc. (Hons.) Thesis. Gomal University, Faculty of Agriculture, Dera Ismail Khan, Pakistan.

Klein, R.N., A.R. Martin, and D.J. Lyon. 2006. Annual broadleaf weed control in winter wheat. NebGuide G1241, University of Nebraska-Lincoln Extension, Institute of Agriculture and Natural Resources, Lincoln, Nebraska, USA.

Labrada, R. 2003. Weed management for developing countries. Addendum 1. Preventive and cultural methods for weed management by Paolo Bàrberi. FAO Plant Production and Protection Paper 120 Add. 1. FAO, Rome, Italy.

Lyon, D.J., A.R. Martin, and R.N. Klein. 2006. Cultural practices to improve weed control in winter weed. NebGuide G1389. University of Nebraska-Lincoln Extension, Institute of Agriculture and Natural Resources, Lincoln, Nebraska, USA.

Malhi, S.S., A.M. Johnston, H. Loeppky, C.L. Vera, H.J. Beckie, and P.M.S. Bandara. 2007. Immediate effects of time and method of alfalfa termination on soil mineral nitrogen, moisture, weed control, and seed yield, quality, and nitrogen uptake. Journal of Plant Nutrition 30:1059-1081.

OMAFRA. 2002. Principles of integrated weed management: Non-chemical weed control. Publication 75. Chapter 1. Ontario Ministry of Agriculture, Food and Rural Affairs (OMAFRA), Ontario, Canada.
Pandey, I.B., and D.K. Dwivedi. 2007. Effect of planting pattern and weed-control methods on weed growth and performance of wheat (Triticum aestivum). Indian Journal of Agronomy 52(3):235-238.

Reddy, S.R. 2000. Principles of crop production. 446-447 p. Kalyani Publishers, New Delhi, India.

Sharma, K.K., S.P. Verma, and C.M. Singh. 1985. Cultural and chemical manipulations for weed management in wheat with reference to grassy weeds. International Journal of Pest Management 31:133-138.

Shrestha, A., B.D. Hanson, M.W. Fidelibus, and M. Alcorta. 2010. Growth, phenology, and intraspecific competition between glyphosate-resistant and glyphosate-susceptible horseweeds (Conyza canadensis) in the San Joaquin valley of California. Weed Science 58:147-153.

Steel, R.D.G., J.H. Torrie, and D.A. Dickey. 1997. Principles and procedures of statistics. A biometrical approach. $3^{\text {rd }}$ ed. p. 400-408. McGraw Hill Book, New York, USA.

Van Der Weide, R.Y., P.O. Bleeker, and L.A.P. Lotz. 2002. Simple innovations to improve the effect of the false seed bed technique. In Proceedings of the $5^{\text {th }}$ EWRS Workshop on Physical and Cultural Weed Control, Pisa, Italy. 11-13 March. European Weed Research Society, Doorwerth, The Netherlands. 